\title{
COLONO ALEMÃO: ABANDONADO OU EXPLORADO?
}

Julieta Beatriz Desaulniers *

\section{Considerações Iniciais}

Este estudo visa reconstruir historicamente os principais mecanismos que socializaram os colonos alemães e seus descendentes, em relação ao trabalho, na colônia de São Leopoldo - província de São Pedro - durante o período de 1824 a $1846^{1}$.

Parte-se aqui do pressuposto de que a socialização e a formação dos indivíduos em seu sentido geral, bem como relativamente ao trabalho, ocorrem tanto através das características estruturais de uma dada sociedade quanto das experiências e vivências desses indivíduos, mesmo que sob aqueles limites estruturais.

Sendo assim, o estudo enfoca os mecanismos provenientes dos setores ou instituições que veicularam as características estruturais da formação social brasileira em que a região em estudo encontrava-se inserida, através da atuação do governo e de sua administração, polícia, legislação, parlamentares, igreja, escola, etc. Sempre que possível, considerou-se as instâncias imperial, provincial e local, o mesmo se fazendo em relação aos mecanismos que emanvam de experiências e vivências culturais dos habitantes da referida região, os quais estavam condicionados por aquelas através da atuação da família, dos vizinhos, da igreja, da religião, da escola, das associações culturais e recreativas.

Partimos do princípio de que as bases estruturais de uma sociedade são constituídas por um conjunto de elementos, os quais devem ser tránsmitidos

${ }^{1}$ Este estudo é parte de um amplo projeto de pesquisa que objetiva reconstruir historicamente a educação e a formação da classe operária do Rio Grande do Sul, no 1 ọperiodo da 1․ República. Tem a coordenação do Prof. Dr. Nilton Bueno Fischer e Prof. Dr. Tomé Tadeu da Silva. Observa-se também que aqui, o significado dos termos colonização e imigração refere-se ao utilizado por Caio Prado Jr., (História Econômica do Brasil, 12 a ed., São Paulo, Brasiliense, 1970). 
aos indivíduos a fim de que ela se mantenha, se solidifique e se perpetue. Mas a formação desses indivíduos não se dá única e exclusivamente por essas características emitidas e veiculadas pelo conjunto de mecanismos e instituições de uma dada estrutura social. Há também outros componentes que corroboram à socialização e formação dos indivíduos: são os que se referem às suas experiências e vivências e que têm um certo nível de autonomia em relação às características da estrutura da sociedade, mesmo que a sua existência ocorra sob aqueles limites estruturais.

Esse processo não se deu pacificamente na área da colonização alemã no período em estudo. Os conflitos se expressaram desde desordens, brigas entre imigrantes, cartas de reclamação dirigidas ao governo quanto às suas atitudes em relação aos recém-chegados até a organização de uma conspiração contra o governo, visando sublevar a ordem vigente.

Basenado-se nas considerações feitas acima é que se procurou compreender ${ }^{2}$ o processo pelo qual se deu a socialização do imigrante alemão e de seus descendentes em relação ao trabalho no período já mencionado.

Geralmente quando se faz menção ao assunto, enfatiza-se ou o papel das características da formação social brasileira junto ao empreendimento dos imigrantes alemães, ou a sua atuação pioneira e desbravadora sem o amparo do Estado brasileiro. Acompanha esta idéia, de forma subliminar, uma outra: a de que o imigrante, que vivia em condições tão ou mais favoráveis em sua terra natal, chegou aqui e não encontrou as mínimas condições de sobrevivência, mas, devido às suas origens, venceu todos os obstáculos que este novo mundo lhe impôs e dele saiu vitorioso. Ou então, quando a abordagem não é unilateral, a interdependência ${ }^{\circ}$ dos fatores que estão indiscutivelmente presentes em qualquer processo de socialização quanto ao trabalho fica pouco evidenciada. O fato é que vem sendo reforçada a conclusão de que os colonos foram abandonados, e poucas são as referências à possível exploração dos colonos pelo Estado brasileiro.

Efetivamente é uma tarefa bastante complexa desvendar com clareza todos os aspectos que estão presentes em uma dada realidade social. Tenta-se aqui fazer isto, mas sabe-se, a priori, que esse estudo, como os mencionados acima, conta também com lacunas.

\section{Delimitações Conceituais}

E importante agora especificar a concepção que terão alguns termoschave no decorrer deste estudo e que foram já mencionados, no pressuposto teórico, tais como: trabalho, educação e socialização relativo ao trabalho.

\footnotetext{
${ }^{2}$ KOSIK, Karel. Dialétida do Concreto. Rio de Janeiro, 1976, p. 188. O significado do termo "compreender" adotado neste trabalho é o exposto por Karel Kosik.
} 


\subsection{Trabalho}

A idéia de trabalho não é unívoca, já que ela envolve um universo complexo, o qual lhe condiciona, como também o torna possível e lhe dá sentido.

Enfatiza-se aqui a concepção de trabalho como o "agir humano objetivo que transforma a natureza e nele inscreve significados, cumprido por necessidade e sob pressão de uma finalidade exterior" ${ }^{3}$, sendo que, basicamente, o que será levantado nesse estudo refere-se aos mecanismos utilizados - nessa região, nessa época e com esses habitantes - como pressão oriunda de uma finalidade exterior, para o agir objetivo desses imigrantes alemães ou de seus descendentes, ou seja, para a realização do seu trabalho (deles) nesse contexto.

Outro aspecto relativo à concepção de trabalho diz respeito à idéia de alienação a ele associada. Esta questão, o lado negativo do trabalho segundo Karl Marx, apresentou-se um tanto difuso do lado dos imigrantes alemães no primeiro período da colonização, no século XIX, nesta Província. Isto porque, em função das necessidades para a instalação e fixação desses recém-chegados, por razões que serão comentadas adiante, de modo geral qualquer desigualdade existente entre eles foi esquecida, a fim de, coesos e unidos, poderem vencer os inúmeros obstáculos. Então, o fato de possuírem uma propriedade, nesse primeiro momento, não gerou a priori relações antagônicas entre eles. Isto passa a se verificar já claramente nos períodos seguintes ${ }^{4}$.

Todavia, a alienação gerada em função do trabalho ocorreu a partir do tipo de relação que se estabeleceu entre esses imigrantes e o Estado brasileiro desde o início do processo de colonização. Vieram para renovar os processos e as relações de trabalho e da produção, constituindo-se em força de trabalho livre, mas através da doação de um lote. Assim, ficaram dependentes, atrelados às condiçôes a eles impostas pelo Estado. $\mathrm{E}$ foi assim - imigrante e Estado que se registraram as relações, que são sempre de oposição entre capital e trabalho. E, conforme Marx, é desta relação, a qual se opera de modo prático, que se origina a alienação.

Segundo Marx o homem pode alienar-se pelo trabalho, de duas formas. Uma delas ocorre quando não há a apropriação do trabalho por quem produz. Neste caso, verifica-se a alienação do trabalhador. A outra forma de alienação

\footnotetext{
${ }^{3}$ Idem, op. cit., p. 188.

${ }^{4}$ Além de outros exemplos, a forma como foi estruturada a obra de Janaina Amado, Conflito Social no Brasil: a revolta dos "Mucker", São Paulo, Ed. Símbolo, 1978, ilustra muito bem isso. O primeiro período da colonização alemã em São Leopoldo - 1824 a 1845 - ela intitulou por igualdade social e o segundo, referente ao período de 1845 a 1875 , por desigualdade social.
} 
"refere-se a quem não trabalha, não produz - o capitalista - e, por isto mesmo estranho à natureza do homem, que é precisamente produzir" 5 .

Sendo assim, tal concepção é aqui considerada, até porque a formação social brasileira na qual a região em estudo estava inserida contava com a diferenciação das pessoas a partir do processo de produção e, decorrente disto, das relaçð̃es sociais de produção. Logo, mesmo implicitamente - já que este não é o ponto central do estudo - a alienação, que é inseparável da realidade e do mundo do trabalho, é também aqui assim entendido.

\subsection{Socialização}

O pressuposto teórico referido no início desta exposição considera que as pessoas não nascem feitas, prontas para o trabalho. Mas, que, para isto, precisam ser formadas, fabricadas, socializadas. Tal fato se dá tanto por meio das características estruturais de uma dada formação social, como também pelas experiências e vivências dos indivíduos, as quais estão condicionadas por aquelas.

Inicialmente, as considerações são feitas em torno do conceito de socialização. Para Galliano, este

"é o processo de aquisição de conhecimentos, padrões, valores, símbolos. É, ainda, a aquisição de maneiras de agir, pensar e sentir próprias dos grupos, da socie dade, da civilização em que $o$ indivíduo vive. Esse processo tem início no instante em que o indivíduo nasce, continua ao longo da vida e só termina quando o indivíduo morre" 6 .

Na concepção de Worsley, aparece um aspecto interessante, que 'o de que esse processo efetiva-se no ato de fazer, de experienciar. Diz ele que socialização é

"a dinâmica da transmissão da cultura, o processo pelo qual os homens aprendem as regras e as práticas dos grupos sociais. (...) Somos socializados através das próprias atividades em que participamos" 7

\footnotetext{
${ }^{5}$ MARX, Karl. Economia Politica e Filosofia. Rio de Janeiro, Ed. Melso Sociedade Anônima, 1963, p. 339-40.

${ }^{6}$ GALliano, A. Guilherme. Introdução d̀ Sociologia. São Paulo, Happer \& Row do Brasil, 1981, p. 303-04.

${ }^{7}$ WORSLEY, Peter. Introdução d̀ Sociologia. Lisboa, Publicações Dom Quichote, 1974, vol. II, p. 203.
} 
Bastante clara é também a concepção exposta por Brandão quanto ao papel que as características das bases estruturais de uma sociedade têm junto ao processo de socialização. Salienta o Autor que

"através da socialização, ao longo da vida, cada um de nós passa por etapas sucessivas de inculpação de tipos de categorias gerais, parciais ou particulares de saber-e-habilidade".

\section{Tais categorias}

"fazem, em conjunto, o contorno da identidade, da ideologia e do modo de vida de um grupo social. Elas fazem, também, do ponto de vista de cada um de nós, aquilo que aos poucos somos, sabemos, fazemos e amamos. A socialização realiza em sua esfera as necessidades e projetos da sociedade e realiza, em cada um de seus membros, grande parte daquilo que eles precisam para serem reconhecidos como 'seus' e para existirem dentro dela" 8 .

Considerando o processo de socialização quanto a um dos aspectos da vida social - o do trabalho -, o que é necessário ter sempre presente é a organização social do trabalho, pois é ela que delimita os atributos indispensáveis a serem assimilados pelos indivíduos em relação ao trabalho. É daí que emana a ética para o trabalho.

Ressalta-se também que o processo de socialização e o de trabalho apresentam aspectos diversos, dependendo do estágio em que se encontram a organização da produção e do trabalho, do grau de formação do trabalhador, assim como do seu grau de organização como grupo. Da mesma forma, os mecanismos e medidas socializadoras, formadoras em relação ao trabalho, variam igualmente em cada estágio ${ }^{9}$.

São dois os principais mecanismos que regem a socialização dos indivíduos: 19) a aprendizagem - que "consiste na aqusição de reflexos, hábitos e atitudes, etc, que se instalam no organismo e no psiquismo do indivíduo e the guiam a conduta" e 29) a interiorização de outrem - que complemente a aprendizagem - ou seja, "é contemplando-se no olhar que os outros lhe dirigem, que uma pessoa constrói o seu si-mesmo, pela imagem de si que pensa dar-lhes e através de juízos sobre si própria que lhes atribui" ${ }^{10}$.

${ }^{8}$ BRANDÃO, Carlos Rodrigues. O que é educação. Rio de Janeiro, Ed. Brasiliense, Coleção Primeiros Passos, 1981, p. 23.

${ }^{9}$ ARROYO, Miguel. Educação e Trabalho. (mimeo.).

${ }^{10}$ GALLiano, op. cit., p. 308. 
É oportuno assinalar que a população a que este estudo se refere é de imigrantes. Sendo assim, eles tiveram seu processo de socialização iniciado no seu país de origem - Alemanha - e concluído no Brasil, na região colonial do Rio Grande do Sul, através de uma ressocialização. Ou seja, foram diversos os elementos que corroboraram a socialização do imigrante alemão e de seus descendentes.

Os mecanismos utilizados pelo capital e pelo Estado para formar-socializar o imigrante alemão e seus descendentes, quanto ao trabalho, não passaram única ou essencialmente pelas escolas, mas até, em certas épocas - em especial a que o estudo se refere -, prioritariamente por outros mecanismos que se mostraram mais educativos.

A partir desse mesmo processo - o da socialização - é possível inferir que o capital, no período em estudo e por meio do Estado, utilizou alguns mecanismos e agentes sociais, para formar-socializar o trabalhador, quanto à ética do trabalho. Houve um processo de educação do imigrante que veio de fora e atuou sobre eles; porém, houve também um processode auto-educação. Eles - os imigrantes - se fizeram e se formaram também de dentro, em sua experiência social e de trabalho, acumulando um saber e uma ética do trabalho ${ }^{11}$.

Através das colocações que já foram feitas sobre socialização, ficou muito claro que esta se processa tanto e, para alguns autores, essencialmente, pelo trabalho como também para o trabalho. Ou seja, no primeiro caso, os indivíduos vão aprendendo a trabalhar, tanto em relação aos aspectos mecânicos da atividade, quanto aos aspectos éticos e sociais da mesma, trabalhando, fazendo, experienciando, junto com outros indivíduos ou a partir do que deles observam. Sendo assim, a socialização vai ocorrendo à medida em que a pessoa vai trabalhando. Neste caso, verifica-se que a socialização se dá pelo trabalho. E, no segundo caso, existem também um conjunto de mecanismos, agentes e instituições que têm o papel de prepara o indivíduo para o trabalho muitas vezes de forma sistemática. Enquanto isto ocorre, ele pode estar ou não ligado diretamente ao mundo do trabalho, da produção.

\subsection{Educação}

De início, deve ser dito que a educação é um processo mais amplo que abrange o da socialização. Ainda deve-se observar aqui que existem inúmeras concepçóes de educação, aliás, fato que acontece em relação a qualquer outro fenômeno, em função das posturas teórico-ideológicas das correntes que existem no campo científico.

Entende-se que 
"a educação do homem existe em toda parte e, muito mais do que na escola, é o resultado da ação de todo o meio sóci-cultural sobre os seus participantes".

E, portanto,

"a comunidade quem responde pelo trabalho de fazer com que tudo o que pode ser vivido-e-aprendido da cultura seja ensinado com a vida - e também com a aula - ao educando".

Ou seja, "a educação existe em toda parte e faz parte dela existir entre opostos" 12 , pois conta com interesses' econômicos e políticos que nela se projetam, e estes nem sempre coadunam-se entre si.

Continuando, salienta-se que esta idéia exposta a seguir, por Brandão, é básica para se captar como se dá, com um certo grau de autonomia, a formação da classe trabalhadora sob as características das bases estruturais de uma dada sociedade. Assim, pode-se compreender melhor algumas atuações dos imigrantes alemães no período em estudo, assim como nos seguintes.

Diz o Autor que

"assim como a vida é maior do que a forma, a educação é maior que o controle formal sobre a educação".

Assinala que

"por toda parte as classes subalternas aprenderam a criar e recriar uma cultura de classe - mesmo quando aproveitando muitos elementos dominantes que lhes foram impostos como idéias ou práticas - e também formas práticas de educação do povo"13.

É importante realçar que a educação "não existe só para difundir o saber, mas para reforçar o resistir" ${ }^{14}$.

Caso esta dimensão da educação seja desconsiderada, como entender, neste estudo, a sobrevivência e organização dos imigrantes alemães e a posição ou manifestação destes frente às ofertas ou solicitações do Estado brasileiro?

\footnotetext{
${ }^{11}$ ARROYO, op. cit., p. 3.

${ }^{12}$ BRANDÃO, op. cit., p. 100.

${ }^{13}$ Idem, p. 103-04.

${ }^{14}$ Idem, p. 106.
} 


\section{A Alemanha em fins do Século XVIII e do Século XIX}

É indispensável tecer algumas considerações sobre certos aspectos históricos dessas áreas que estão envolvidas nesse movimento migratório. Isto para deixar claro que existiram circunstâncias favoráveis ao referido movimento, no interior de ambas as nações - Alemanha e Brasil. E, ainda, que o alemão que tomou a decisão de emigrar foi pressionado muito mais pelas condições materiais de que ali tinha acesso do que pelas vantagens que o Brasil propagava assegurar aos que para cá se dirigissem.

A Europa, nos fins do séc. XVIII e parte do séc. XIX, estava, genericamente, subdividida em três áreas distintas, dependendo das posições que as nações ocupavam tanto em relação às mudanças da conjuntura econômica e política internacional, como também em relação àquelas que se referiam ao seu desenvolvimento e à sua ação política. Basenado-se nestes critérios, a GrãBretanha, a França e parte da Holanda ocupavam a primeira posição. As principais áreas que ocupavam a segunda posição eram a Austria, a Espanha e Portugal, e a terceira posição correspondia àquelas nações que, retalhadas, foram submetidas ao domínio de outros países (principalmente dos que ocupavam a primeira área - a posição de dominadores em relação às outras áreas). Aqui estavam os principados, ducados e reinos italianos, alemães e da Polônia ${ }^{15}$.

De alguma forma, também a Revolução Francesa (via doutrina liberal e Império Napoleônico) contribuiu para desestabilizar o poder da monarquia absoluta, mantida em quase todos os Estados alemães. Porém, com a queda do Império Napoleônico, restaurou-se a doutrina da legitimidade, a qual novamente firmou as bases para o poder absoluto dos nobres. Como as posses de terra estavam nas mãos da nobreza, grande parte da população não teve acesso aos meios de produção, pois até 1830 nada mais se fez do que fortalecer os direitos dos nobres que passaram a se atirar com redobrada ganância em cima das camadas baixas da população. Em decorrência disto, não tinham como prover sua subsistência ${ }^{16}$. Em tais condições, o descontentamento dos trabathadores era generalizado, mas caso procurassem defender os seus interesses, eram reprimidos e equiparados aos criminosos comuns, aos desordeiros ${ }^{17}$.

Fatores como a revolução agrícola e demográfica contribuíram para o desenvolvimento do seu processo de industrialização. A abolição da estrutura feudal, após a revolução agrícola, foi favorável ao camponês médio, que se

${ }^{15}$ SCHALLENGERGER, Erneldo \& Hartmann, H. Roque. Nova Terra, Novos Rumos. Santa Rosa, Barcellos Livreiro e Editor, 1981, p. 16.

${ }^{16}$ SCHALLENBERGER, e Hartmann Erneldo. Op. cit., p. 17.

${ }^{17}$ DUROSELLE, J.B. A Europa de 1815 aos nossos dias - vida politica e relaçóes internacionais. São Paulo, Pioneira, 1976, p. 4. 
tornava proprietário após ter cedido $1 / 3$ ou metade de suas terras ao senhor, podendo garantir a propriedade do que lhe restava e realizar uma exploração contínua, suficiente para sua familia.

Já o pequeno camponês obteve apenas uma diminuta exploração, a qual não representava mais do que um recurso econômico. Então, para sobreviver era obrigado a se empregar como trabalhador agrícola sob as ordens do senhor, vender o que lhe restava ou arrendar terras suplementares. Com o "retalhamento dessas pequenas propriedades, foi gerando progressivamente um segmento social no mundo agrícola denominado de "homens sem terra" ${ }^{18}$. Para estes não restava outra alternativa senão a emigração ${ }^{19}$ a fim de conseguirem melhores condições de vida.

A partir de tais consideraçôes, verifica-se que as primeiras levas de imigrantes alemães, que se dirigiram ao Brasil, foram expulsas de suas regiões por questôes relacionadas à estrutura econômica lá existente referentes ao setor agrícola e não ao industrial, o qual irá condicionar a emigração somente após a segunda metade do séc. XIX. Ou seja,

"a emigração não foi uma válvula de escape de tensões momentâneas. Foi um processo que se prolongou por quase um século. Nesse período, houve consideráveis transformações sociais, acompanhadas de maior ou menor tensão, que fizeram com que se transformassem as causas da emigração" 20 .

Ainda, conforme Weimer, "em toda a parte a vida do camponês era dura e frugal". Cita que no Eleitorado de Hesse-Kassel, o Grande Eleitor dispunha de seus súditos como se fossem gado, inclusive vendendo-os como soldados aos ingleses, quando da guerra da Independência dos Estados Unidos, fazendo o mesmo, mais tarde, para servirem de agricultores nos Estados Uni$\operatorname{dos}^{21}$.

Aos camponeses "livres", que não tinham mais vínculos de servidão, a situação não era tão diferente, pois tinham que pagar altas taxas e impostos estando sujeitos, às vezes, a trabalharem gratuitamente por certo tempo ao Estado ou para o senhor feudal. Em suma, suas condições de vida eram muito

${ }^{18}$ SCHALLENBERGER \& HARTMANN, op. cit., p. 19.

${ }^{19}$ WILLEMS, Emılio. Assimilação e populaçōes marginais no Brasil - estudo sociológico dos imigrantes germânicos e seus descendentes. São Paulo, Nacional, 1940, p. 431.

${ }^{20}$ WEIMER, Günther. $A$ arquitetura da imigração alemã; um estudo sobre a adaptação da arquitetura centro-européia ao meio nural do Rio Grande do Sul. Porto Alegre, Ed. da Universidade, UFRGS; São Paulo, Nobel, 1983, p. 16.

${ }^{21}$ Idem, p. 24. 
precárias, sendo a fome uma ameaça constante. Produziam o que consumiam, desde o pão até o vestuário. A situação era tal que

"uma colheita mal-sucedida ou um inverno muito rigoroso, inapelavelmente, liquidava com uma fatia da população" 22 .

Ao expor as condições mais gerais que caracterizavam a Alemanha em fins do séc. XVIII e parte do séc. XIX - estrangulamento das estruturas econômicas internas, clima de insegurança política, graves problemas sociais -, fica claro que havia, nessa área européia, as mais diversas razões para que uma determinada camada da população - em especial a camada inferior, "o povo" - recorresse à emigração. Isto porque era o que lhe restava fazer, a fim de garantir a sua sobrevivência de forma mais digna. Sendo assim, não foi uma opção o fato de emigrar para a América, e sim a tábua de salvação para este segmento da população alemã.

\section{O Brasil do Século XIX}

A seguir serão expostas as principais condições do contex to brasileiro referentes ao Séc. XIX que viabilizaram a imigração e colonização alemã. Ê a partir desta época, que se inicia um processo colonizador e imigratório, oriundo de uma política intencional do governo, o qual tem vinculações com a transferência da Coroa Portuguesa para o Brasil (auxiliada pelos ingleses) e a conseqüente abertura das portas às "nações amigas". Vale destacar a introdução do capitalismo industrial, na Inglaterra, que tinha necessidades (mercado consumidor para escoar suas manufaturas) diferentes das do capitalismo comercial (conquista e ocupação), as quais demandaram alterações profundas em alguns setores, até então estratégicos, da economia do país. Entre eles, o da escravidão, que se constituíam num grande obstáculo ao capitalismo industrial, já que tal forma de trabalho privava o escravo do poder aquisitivo.

Então, a vinculação anteriormente mencionada entre imigração e vinda da Corte Portuguesa para o Brasil e abertura dos portos refere-se à "transformação do regime de trabalho da sociedade brasileira". Ou seja, substituição da força de trabalho escrava por força de trabalho livre, assalariada. Logo, "a imigração européia, que veio para o Brasil no séc. XIX, está intimamente ligada ao problema da escravidão" 23 .

\section{${ }^{22}$ Idem, p. 24.}

${ }^{23}$ LANDO, Aldair M. \& Barros, Eliane C. Capitalismo e Colonização - os alemães no R.S. In: Dacanal, José H. \& Gonzaga, Sergius, Org. R.S.: imigração \& colonização. Porto Alegre, Mercado Aberto, 1980. 280 p. (Série Documento) p. 11. 
A inserção do imigrante europeu, no contexto brasileiro, deu-se de forma diferenciada e peculiar, em função das condições e necessidades específicas de cada região ou província brasileira.

É importante considerar que o fato de buscar população estrangeira para assegurar a substituição do trabalho escravo pelo livre evidencia, por parte do Império, uma discriminação em relação aos brasileiros. Para Giron, "o Império proporcionou aos europeus aquilo que negou aos seus súditos" 24 . É este, também, o ponto de vista de Celso Furtado, quando diz que

"as colônias criadas em distintas partes do Brasil pelo governo imperial careciam totalmente de fundamento econômico; tinham como razão de ser a crença na superioridade inata do trabalhador europeu, particularmente daqueles cuja 'raça' era distinta da dos europeus que tinham colonizado o país" 25 .

Inclusive as despesas realizadas pelo governo seriam bem menores caso utilizasse o elemento nativo e não o estrangeiro para implantar as necessitadas mudanças nas relações de trabalho.

Entretanto, conforme Oberacker Junior, a imigração para o governo imperial constituía-se num problema cultural e "não numa questão de braços", de sucedâneo para os escravos como entendiam os fazendeiros, que tinham transformado a questão da imigração em "garantia do seu domínio de clas$\mathrm{se}, 26$.

Em resumo, era patente a preocupação do Imperador (assessorado nisto por José Bonifácio e Dona Leopoldina) em viabilizar, através da imigração, mudanças na maneira como era encarado e realizado o trabalho até então no Brasil.

Porém, o ponto de vista do Governo imperial, relativo à imigração, não era o dominante, menos ainda na fase inicial do movimento imigratório. $\mathrm{O}$ primeiro período da colonização foi conduzido, essencialmente, pelas concepções de trabalho dos setores governamentais ou da elite - que conheciam e conviviam com o trabalho escravo -, as quais visavam, essencialmente, assegurar o seu domínio de classe. Percebiam os imigrantes alemães do mesmo modo que os escravos, visto que dedicavam-se a trabalhos manuais. Sendo assim,

${ }^{24}$ GIRON, Loraine Slomp. A imigração italiana no RS: fatores determinantes. In: Dacanal, José H. \& Gonzaga, Sergius. Org. R. S.: imigração \& colonização. Porto Alegre, Mercado Aberto, 1980, 289 p. (Série Documento 4) p. 55.

${ }^{25}$ FURTADO, Celso. Formaçāo econômica do Brasil. São Paulo, Nacional, 1972, p. 124.

${ }^{26}$ OBERACKER Junior, Carlos $\mathrm{H}$. A contribuição teuta à formação da nação brasileira. Editora Presença, Rio de Janeiro, 1968, p. 301. 
eram tratados, na maioria das vezes, como servis e inferiores em relação às outras camadas sociais.

As colocações descritas acima aparecem muito bem sintetizadas nas palavras do Ianni. Para ele o fenômeno migratório constituiu-se, efetivamente, num "movimento da força de trabalho num mercado de força de trabalho mundial que então se criou". Isto porque, para o mesmo autor, tal fenômeno,

"havido do Séc. XIX ao Séc. XX, estava diretamente ligado à expansão do capitalismo europeu e às transformações das estruturas políticas, econômicas, sociais vigentes na Europa, feudalismo e, no Brasil, escravidão" 27.

É importante tecer considerações em torno do que o governo brasileiro esperava com a colonização alemã, assim como, das estratégias por ele utilizadas para atrair o imigrante alemão. A primeira delas e de ordem mais imediata era a de povoar e ocupar regiões de valor estratégico, as quais se encontravam conturbadas por questões de limites com a Coroa espanhola. Associada a essa preocupação, objetivava-se também

"ativar a produção agrícola, de modo a compensar o desequilíbrio, numa economia ainda frágil, resultante do absoluto domínio da pecuária” ${ }^{28}$.

Outra expectaviva do governo brasileiro, de ordem mais mediata, era a de que a produção agrícola das colônias pudesse abastecer também outras regiões do Brasil, de gêneros alimentícios de que mais necessitavam, pois com a

"expansão da cultura do café, a qual dava maior margem de lucro, o cultivo de cereais e gêneros alimentícios foi, em boa parte, deixado de lado. Também, com isso, verifica-se, mais uma vez, o caráter de economia complementar do setor exportador da economia nacional, que caracterizava a produção gaúcha" 29 .

${ }^{27}$ IANNI, Octávio. Aspectos políticos e econômicos da imigração italiana, In: Imigração italiana: estudo. Caxias do Sul, UCS - EST, 1979, p. 11-2.

${ }^{28}$ CESAR, Guilhermino. Ocupação e diferenciação do espaço. In: Dacanal, José H. \& Gonzaga, Sergius, org. R.S. economia \& politica. Porto Alegre, Mercado Aberto, 1979, p. 22.

${ }^{29}$ CARDOSO, Fernando Henrique. Capitalismo e escravidão no Brasil Meridional. São Paulo, Difusão Européia do Livro, 1962, p. 219-20. 
A intenção do governo em transformar o regime de trabalho até então vigente no país pode ser constatada pelo exame das le $\mathrm{is}^{30}$ do Governo Central ou das Províncias, onde se tomavam certas medidas proibindo a coexistência de escravos e estrangeiros numa mesma colônia. Por ex., quanto à fixação dos alemães, verifica-se que se localizaram em regiōes onde a participação do trabalho escravo era insignificante.

É interessante tambem considerar como se implantou a colonização na Província, o que viabilizou o processo de formação da pequena propriedade. Assim, o Governo Imperial visava a reduzir o poderio dos grandes proprietários $^{31}$.

E indiscutível o significado da imigração estrangeira, para o Brasil a partir so séc. XIX. Neste sentido, alguns autores afirmam que

\section{"a atitude imigrantista constitui-se numa crítica à sociedade tradicional em dois sentidos: introdução do trabalho livre e consolidação da pequena propriedade" ${ }^{32}$.}

Dentre as estratégias utilizadas pelo governo brasileiro, menciona-se as vantagens ${ }^{33}$ por ele propagadas aos que migrassem para o Brasil. Observa-se, porém, que foi propagada na Alemanha a obtenção das primeiras levas, em fevereiro e março de 1824 . Esses termos do compromisso, além de nem sempre terem sido cumpridos, foram sendo alterados e até restringidos no decorrer do período migratório.

\section{Aspectos Gerais da Província no início do Séc. XIX}

A Província encontrava-se, nessa época, em prosperidade econômica, devido às atividades agropecuárias $\mathrm{e}$ às charqueadas.

A colonização foi uma decisão do governo central. 0 poder regional, representado pelos senhores de terra, não tinha interesse nisso e nem estava dis-

${ }^{30}$ Uma das leis qe esclarece o que foi acima mencionado, refere-se à lei no 514 , de 28.10.1848, art. 16. In: Coleção das do Império. Tipografia Nacional, 1949, tomo 10, parte 1.

${ }^{31}$ LANDO, Aldair M. \& Barros, Eliane C. Capitalismo e Colonização - os alemães no Rio Grande do Sul. In: Dacanal, José H. \& Gonzaga, Sergius, Org. $R$ S. : imigração \& colonização. Porto Alegre, Mercado Aberto, 1980, 280 p. (Série Documento, 4) p. 41.

${ }^{32}$ Idem, p. 43.

${ }^{33}$ Consultar Relatório apresentado ao Governo da Província pelo Dr. João Daniel Hillebrandt - ex-diretor das Colônias - 1854. In: Revista do Arquivo Público, RS., nọ, p. 15-16. 
posto a partilhar o poder com os recém-chegados. Ainda mais que a política de D. Pedro I pretendia instalar núcleos de pequenos proprietários para ofuscar o poder dos grandes proprietários.

As características peculiares dessa Província, tais como: a solidez de sua hierarquia, o gosto das armas e a valentia, o amor ao cavalo, o desdém pela agricultura, pelas artes mecânicas e pelo conforto material ${ }^{34}$, exerceram influências significativas não só na vida política, como também no processo de socialização do imigrante alemão em relação ao trabalho, quando aqui se instalou.

\section{Fatores Condicionantes do Processo Socialização/T rabalho}

Como já foi dito, o governo tinha várias expectativas em relação à colonização. Resta saber o que ele fez para a sua concretização. Ê importante que se dê resposta a esta questão, pois assim identifica-se como o Estado socializou o imigrante alemão e seus descendentes ao trabalho.

Também os imigrantes alemães depositaram algumas esperanças em relação à sua vinda para o sul do Brasil. Certos segmentos da sociedade brasileira, como os senhores de terra, por exemplo, tinham também suas posições quanto ao processo de colonização proposto pelo Estado. Como tais questões foram sendo respondidas, concretizadas, tanto pelos imigrantes alemães e seus descendentes quanto pelos senhores de terra?

As respostas a estas indagações igualmente contribuem para se compreender a forma como se realizou a socialização em relação ao trabalho referente à população em estudo. Outrossim, evidenciam que tal fenômeno não é definido apenas pelos interesses do governo central e/ou provincial, ou dos senhores de terra, mas é definido também pelos dos imigrantes. E é deste jogo de interesses, por vezes antagônico, que resulta todo e qualquer processo de socialização, assim como o que formou o imigrante alemão e seus descendentes para atuarem no campo do trabalho no período analisado.

E importante observar que as considerações a serem feitas aqui visam a apontar a atuação (manifesta ou latente) tanto das características das bases estruturais da sociedade brasileira da época, as quais se materializaram através dos vários elementos que compunham o Estado,quanto a das experiências e vivências dos imigrantes alemães - os já pertencentes à sua história quando aqui chegaram e as que vão aqui se estruturando -, as quais se utilizaram de mecanismos para se evidenciar, entre eles, a família, a escola, a religião, a igre-

${ }^{34}$ Maiores detalhes consultar ROCHE, Jean. A coloniz ação alemã e o Rio Grande do Sul. Porto Alegre, Editora Globo, 1969, p. 777. 
$\mathrm{ja}$, as atividades produtivas, recreativas e culturais. Isto porque foi neste jogo de relações com interesses contraditórios e até antagônicos entre as características das bases estruturais da sociedade brasileira da época e experiências e vivências dos imigrantes, os quais, em certa medida, estavam condicionados por essas, é que se processou a socialização referente ao trabalho neste período e nessa região.

\subsection{Administração}

As primeiras providências quanto à instalação dos imigrantes alemães foram tomadas por ordem do Imperador, pela administração do governo provincial e referiam-se à demarcação dos lotes da Imperial Feitoria do Linho Cânhamo.

Sabendo o governo imperial das inúmeras tentativas fracassadas de colonização de várias regiões do Brasil ${ }^{35}$, averiguou-se o fato e admitiu-se que se devia à
"repugnância pelo trabalho físico, tido geralmente como con- dição humilhante destinada apenas aos escravos e não ao ho- mem branco. Como homens livres, não estavam dispostos a se rebaixarem perante o mundo ambiente, trabalhando como es- cravos" ${ }^{36}$.

Frente à concepção degradante que o trabalho manual assumiu na época, o Estado "lançou mão de elementos colonizadores que estavam imbuídos de idéias divergentès daquelas dos imigrantes da época colonial", e por isso especialmente os alemães, pela diferença étnica e lingüística ${ }^{37}$, estavam "imunes e impermeáveis à mentalidade colonialista vigente, que até então impedia 0 surgimento de uma classe média" ${ }^{38}$.

Porém, a imunidade só seria garantida caso eles fossem localizados em áreas segregadas, formando grandes comunidades coloniais, a fim de que pudessem resistir aos preconceitos contra o trabalho manual. Conforme Oberacker, "os estadistas de responsabilidade do Império, e até entrando muito pelo período republicano", estavam convencidos da necessidade das colonizações serem etnicamente segregadas ${ }^{39}$.

\footnotetext{
${ }^{35}$ Mais informações, consultar Carlos H. Oberacker Junior, op. cit., p. 207-08. ${ }^{36}$ OBER ACKER Junior, op. cit., p. 208.

${ }^{37}$ Efetivamente, a questão referente à imigração era cultural e não étnica. $\mathrm{O}$ governo $\mathrm{Im}$ perial temia que se constituísse aqui não um "Império de Negros" e sim um "Império de preguiçosos".

${ }^{38}$ OBERACKER Junior, op. cit., p. 210.

${ }^{39}$ Idem, p. 210.
} 
Mas o que deve ficar bem claro quanto ao papel da administração, nesse sentido, é o de que ela garantiu, efetivamente, por vários mecanismos - leis foram emitidas proibindo a coexistência de escravos nas colônias alemãs - a segregação dos imigrantes alemães que se dirigiram para essa Província. Tanto que se afirma ser a segregação étnico-lingüística, a qual isolava São Leopoldo da mentalidade econômica então vigente, um dos principais fatores de sua prosperidade $^{40}$.

A distribuição de terras foi muito morosa e cheia de falhas, apesar da portaria de criação da nova colônia ser de 31.03 .1824 e determinar a divisão do terreno da Feitoria imediatamente ${ }^{41}$. E, mais do que isto, os colonos eram explorados pelos que distribuíam os víveres fornecidos pelo governo, para proverem suas necessidades básicas.

Aí começa a atuação inoperante do governo, devido à sua inexperiência no setor, juntamente com sua concepção relativa ao trabalho. Lembra-se que a percepção mais lúcida sobre a questão do trabalho manual restringia-se ao Imperador e assessores diretos. De resto, o pensamento que dominava era o da concepção vigente na época. Enfim, os seus contatos mais diretos até então restringiam-se ao comando e controle do trabalho dos escravos.

Enquanto aguardavam a demarcação dos lotes, estavam entregues à vadiagem, o que desencadeava desde brigas entre eles, por qualquer razão, até a bebedeira. Mas esta situação criada pela morosidade da administração não ficou só nisto. Os imigrantes começaram também a manifestar a sua insatisfação, reclamando ao inspetor os problemas e prejuízos que estavam tendo enquanto não recebiam os seus lotes. Pretendiam ir a Porto Alegre para reclamar junto ao Governo "empregando mesmo a força se isso fosse necessário" 42 .

As autoridades tomaram medidas enérgicas e conseguiram frustrar tal intento. Para lá foi indicado o tenente-general Bento Correia de Câmara, alta patente do exército imperial, ficando à sua disposição em São Leopoldo, um pequeno destacamento de força ${ }^{43}$.

Ao inspetor da Colônia também pareceu necessário elaborar e aplicar um regulamento, semelinante ao da polícia, com medidas repressivas, o qual foi aplicado por um ex-suboficial dos batalhões alemães.

Conclui-se que a administração, em alguns aspectos, era morosa e inoperante e em outrö demonstrava habilidade e decisão, conforme os fatos men-

\footnotetext{
${ }^{40}$ Idem, p. 213.

${ }^{44}$ HUNSCHE, Carlos H. Primórdios da vida Judicial de São Leopoldo. Porto Alegre, Escola Superior de Teologia São Lourenço de Brindes, 1979, p. 14.
}

${ }^{42}$ PORTO, Aurélio. $O$ trabalho alemão no R. G.S. Porto Alegre, Estabelecimento Gráfico Sta. Terezinha, 1934 , p. 51.

${ }^{43}$ Idem, p. 51. 
cionados anteriormente. É provável que o tipo de atuação estava em relação direta com os seus interesses. Observa-se que tomou as providências mais essenciais, dando sempre destaque à ordem, pois assim estava viabilizando as condições necessárias ao trabalho.

Ainda por iniciativa do inspetor da Colônia, dois médicos que aí atuavam passaram a ser pagos pelo governo brasileiro. Dois pastores alemães receberam uma casa e uma sala para culto a partir de 1824. Em 1825, um pároco católico foi nomeado capelão de São Leopoldo e, em 1828, começava a construção de uma capela, onde mais tarde - entre 1845 e 1859 - construiu-se a Igreja Matriz Nossa Senhora da Conceição.

A administração, ao perceber as dificuldades enfrentadas pelos colonos - que começaram a trabalhar às tontas e mesmo assim estavam obtendo co- lheitas razoáveis -, deu-lhes algumas orientações a respeito do solo, das plantas, do ritmo das estações. Fez isto através da distribuição de dois dicionários de agricultura.

A administração concedeu ao imigrante espécies de "modus vivendi" exercer a profissão que aprendeu na Alemanha - não para satisfazer as necessidades ou dificuldades pessoais dos colonos, e sim porque esse mecanismo agilizaria o desenvolvimento econômico da colônia, fazendo com que a mesma, ao invés de onerar o governo, passasse a se constituir em fontes de lucro para ele o para certos setores da localidade e de Porto Alegre inicialmente ${ }^{44}$.

Os reflexos dessa concessão também são comentados por Oberacker quando diz que

"não era a colônia de São Leopoldo assim, de fato, um conglomerado de pequenos estabelecimentos agrários rurais, porém uma comunidade socialmente concatenada" 45 .

A Lei do Orçamento, de 15 de dezembro de 1830 , a qual suprimiu todos os créditos à colonização, gerou uma série de problemas aos imigrantes alemães e, em decorrência disto, a toda a dinâmica da vida da colônia de São Leopoldo ${ }^{46}$.

${ }^{44}$ Afinal, já na seleção dos imigrantes, isso foi levado em conta. Diz Oberacker que "o major von Shaeffer, tão injustiçado, demonstrou ser homem de larga visão, aliciando não só lavradores, como hábeis artesões, técnicos industriais e comerciantes, com disposição empreendedora, professores, sacerdotes e médicos. Assim os colonos não eram, de modo algum atirados à sorte e sem assistência na mata virgem". (In. Oberacker, op. cit., p. 212). ${ }^{45}$ OBERACKER, op. cit., p. 212-13.

${ }^{46}$ Maiores considerações sobre as decorrências dessa Lei inclusive a tentativa de sublevação da ordem vigente por parte dos imigrantes - constam no item que aborda a legislação referente à colonização e imigração alemãs. 
Uma das alterações refere-se à substituição do inspetor da Colônia, José Tomás da Silva, o qual já estava bastante identificado com os problemas e ne. cessidades dos colonos e, por isso, muito respeitado e aceito por eles.

Frente ao elevado grau de insatisfação contra o governo era necessário, nesse momento, outro tipo de inspetor, que fosse mais rígido e severo com os colonos, isto é, que não tolerasse qualquer reclamatória e os mantivesse sempre em seu lugar: trabalhando, e não reivindicando ou reclamando.

O indicado para ocupar esse cargo, em 19 de julho de 1831 , foi o "tenente coronel Salustiano Severino dos Reis, oficial do exército imperial, já residente em São Leopoldo". E, conforme o que se queria, ele era "mais soldado do que administrador, vindo das velhas tarimbas das guerras do sul, acostumado ao regime de disciplina férrea do tempo" e tratava "(...) os colonos como soldados insubmissos" 47 .

Outros mecanismos controladores da reação dos imigrantes e que os submetesse ao trabalho foram necessários. Criou-se com urgência os Juízo de Paz na Colônia de São Leopoldo que contava com atribuições judiciais administrativas e policiais. Quanto a esta última, cabia também "exercer inspeção sobre vadios e mendigos, no sentido de fazê-los trabalhar" 48 .

Pode-se dizer que os colonos tinham a seu lado um administrador natural, em função da liderança que ele exercia junto à maioria. Este papel de destaque cabia ao Dr. Hillebrandt que era também benquisto pelo governo imperial $^{49}$. Representou, em muitos momentos, os interesses e as necessidades dos imigrantes e também era o intermediário dos colonos junto ao Estado ou viceversa. É inquestionável, porém, o fato de ter sido um elemento que exerceu grande influência junto aos imigrantes em todos os sentidos e, assim, pelas suas atuações, propunha sutilmente atitudes e valores relativos ao trabalho que foram incorporados pelos imigrantes.

Menciona-se ainda a habilidade da administração, que ao perceber o progresso da Colônia, propôs a sua emancipação - em 1846 -, a qual era sentida como necessidade também pelos próprios imigrantes alemães que estavam na vanguarda da economia da região.

A partir das considerações feitas neste item, verifica-se que algumas situações ficaram patentes. Dentre elas, a de que os imigrantes, mesmo que muitas vezes extorquidos, enganados e desprezados, não foram abandonados ou esquecidos pelo Estado, já que este sempre se fez presente para explorar e/ou para reprimir.

\footnotetext{
${ }^{47}$ PORTO, op. cit., p. 119.

${ }^{48}$ HUNSCHE, op. cit., p. 34.

${ }^{49}$ Várias considerações sobre isso, especialmente em Porto, op. cit., p. 94-5-6 e 129.
} 
Fica claro também, a contribuição do Estado para a socialização dos imigrantes alemães em relação ao trabalho. Foram laboriosos trabalhadores, como se assinala com freqüência, graças também à presença e interferência das características das bases estruturais da sociedade brasileira na época.

Outra situação que ficou evidenciada diz respeito à atuação dos imigrantes alemães perante a do Estado. Não foram submissos e passivos frente às condições que lhes proporcionavam. Sabiam, de alguma forma, porgue vieram para cá e o que daqui queriam obter. Por isso, mesmo sendo forte a repressão aos seus manifestos de descontentamento, sempre procuraram expressá-los, de forma mais veemente ou mais restrita. Isto para não deixarem cair por terra o seu projeto de vida, o qual se sustentava no trabalho, só que baseado em algumas condições acenadas pelo governo brasileiro.

Essa posição dos imigrantes frente à atuação do Estado brasileiro corroborou também à sua socialização em relação ao trabalho, o qual assumiu características peculiares ao que vigorava até então no Império. Forçaram o Estado a se aperceber de que eles, mesmo dedicando-se ao trabalho braçal, não se portavam como escravos. Assim, com o passar do tempo, apesar de ainda se defrontarem com tais preconceitos, constituíram uma nova categoria social ainda inexistente aqui - a qual diferenciou-se significativamente da dos escravos, em função de seus empreendimentos na região colonial.

\subsection{Legislação}

Este foi outro expediente com o qual o Estado exerceu força e poder frente aos colonos, especialmente no primeiro e segundo períodos de colonização alemã. Foi um aspecto que durante quase todo o século XIX esteve totalmente sob o seu controle, já que raros foram os imigrantes alemães ou descendentes que ocuparam a legislatura nesta época. Associado a isto estavam as dificuldades existentes à naturalização, a qual poderia reverter em algum poder para os imigrantes junto à esfera governamental.

Assim, as principais decisões, a nível legal, sobre a colonização alemã foram tomadas à revelia dos diretamente interessados.

No período de 1824 a 1846 , algumas leis foram decisivas para as condições de vida e de trabalho dos imigrantes alemães.

Já antes de terem chegado ao Brasil, a Constituição do Império criava alguns impecilhos a eles em função das promessas feitas pelo representante do governo brasileiro na Alemanha. Constava em seu contrato a liberdade de culto, isenção de pagamento de impostos e a naturalização imediata, mas tais promessas eram inconstitucionais.

Em geral, as leis referentes à naturalização na fase imperial continham várias restrições ou exigências em relação aos imigrantes, o que estava direta- 
mente relacionado com a posição da elite da sociedade brasileira nesta fase, a qual detinha o domínio da economia e da política. Sendo assim, concediam aos imigrantes a condição de cidadãos, em circunstâncias estratégicas e com as restrições necessárias à garantia e respaldo de seus privilégios.

Ainda, pontos referentes ao contrato: a religião protestante, não sendo aceita como legal pela Constituição, colocou os protestantes numa situação muito delicada, já que o governo estava fazendo vista grossa para este fato, pagando salários até aos pastores. Esperava-se que retribuíssem estes favores não reclamando e não reivin dicando coisas ao governo.

Esse foi um mecansimos muito sutil utilizado pelo Estado, o qual auxiliou também a repressão das manifestações de resistência e revoltas dos imigrantes contra o Estado ${ }^{50}$.

A legislação referente à imigração quanto aos direitos e deveres dos que para lá se dirigiam era muito inconstante, favorecendo um clima de instabilidade e insegurança aos alemães, o que deixava-os vulneráveis não só frente ás investidas do Estado como também às de alguns imigrantes mais espertos que se sobressaíam economicamente e passavam, já nesse período, a explorar o agricultor.

Também a denominada Lei do Orçamęnto é deste ano - 15 de dezembro de 1830 - e oficializou a eliminação de todos os créditos para a colonização estrangeira, anulando então todo o compromisso do governo imperial com os imigrantes alemães, ignorando, inclusive, os termos da própria Constituição Imperial $^{51}$.

As dificuldades dos imigrantes foram aguçadas com essa Lei do Orçamento. Também a forma como ela foi aplicada - negando a Constituição elevou o nível de insatisfação dos imigrantes alemães sensivelmente, redobrando, assim, a sua desconfiança em relação do Estado brasileiro ${ }^{52}$.

Frente a tais impecilhos, as últimas levas que aqui chegaram foram precariamente subsistindo ${ }^{53}$, graças ao auxillio dos colonos estabelecidos aqui há mais tempo.

Em geral, as referências à colonização alemã no Rio Grande do Sul men-

\footnotetext{
${ }^{50}$ Este fato é significativo já que em São Leopoldo, em 1845 , os habitantes evangélicos representavam $64 \%$ da população e os católicos $36 \%$. (In: Arquivo Histórico do R.G.S., colonização, códice 182).

${ }^{51}$ Consultar Revista do Arquivo Público n? 15-16, 1924.

${ }^{52}$ ROCHE, op. cit., p. 99.

${ }^{52}$ Ainda, em julho de 1834 , iam até o governo provincial solicitar o pagamento de seus subsídios o qual deixaram de pagar, a partir de 1830. (Conforme Correspondência expedida pelo Presidente da Província ao Secretário da Câmara dos Deputados; Arquivo Histórico do R.G.S., A-\$-69, 26.7, 1834, p. 115).
} 
ciona a pouca participação política dos imigrantes na época imperial. No primeiro período desta fase - 1824 a 1846 -, tal participação teria praticamente inexistido ${ }^{54}$.

Porém, "uma das formas de participar da vida política de uma nação é a participação em seus conflitos" ${ }^{55}$. Neste sentido, os imigrantes nem bem tinham chegado aqui e iá estavam participando politicamente, mesmo à força, pois foram envolvidos nas guerras da Província registradas nesse período, apesar de constar no seu contrato, ao emigrarem, que isto não faria parte de suas atribuições, bem como qualquer outro tipo de serviço militar ${ }^{56}$.

Inicialmente, foram solicitados a participar da Guerra Cisplatina (18251828). Foi uma experiência dolorosa e a Colônia de São Leopoldo sofreu suas repercussões - morais e materiais.

Outra guerra, e esta mais longa e desencadeada em certos momentos na própria área da colônia, foi a dos Farrapos, que durou de 1835 a 1845.

Nesses poucos anos de existência, apesar dos vários percalços, a colônia tornara-se importante centro econômico da Província e, por isso, de grande relevância estratégica e econômica. Na realidade, os farrapos contavam com adeptos entre os imigrantes alemães, principalmente os intelectuais e os antigos oficiais ${ }^{57}$ que, em grande parte, haviam abandonado a Alemanha pós-napoleônica por motivos políticos.

Havia, contudo, um forte opositor à causa dos farrapos, o qual como se viu, usufruía um grande prestígio entre os colonos: o Dr. Hillebrandt. Mesmo com a população da colônia estando dividida em partidários dos farrapos de defensores do Império, ele conseguiu a adesão da maioria à posição que defendia. Sendo assim, a Colônia de São Leopoldo constituiu-se no primeiro foco de reação efetiva ao governo farrapo de Porto Alegre.

Nos primeiros anos do processo revolucionário, algumas vezes a área colonial alemã foi cenário de algumas lutas ${ }^{58}$. Isto resultou em um clima de hostilidade entre os próprios imigrantes, já que havia divergências de posição en-

${ }^{54} \mathrm{Há}$, inclusive, afirmações categóricas neste sentido, como esta por exemplo: "Os imigrantes alemães de São Leopoldo não tiveram nenhum tipo de participação política até 1845 ". (Conforme Amado, op. cit., p. 51).

${ }^{55}$ CUNHA, Neusa Maria Costa. Participação política dos imigrantes alemães em São Leopoldo, Separata do Anuário de 1972 - IESPE - PUC - RS.

${ }^{56}$ OBERACKER Junior, op. cit., p. 216.

${ }^{57}$ Entre eles figuravamo major Frederico Otto Heisse, o capitão Hermann von Salisch, João Frederico Krieger, Frederico Engerer, tenente Antônio Ludovico Schðđer, João Jacob Agner, o pastor Cristiano Klingelhøffer e seu filho Hermann.

${ }^{58}$ Estas são referidas, com detalhes, especialmente, na obra de Porto, op. cit., p. 120 a 128. 
tre eles ${ }^{59}$. Além de trazer prejuízos à área construída da povoação, e também didiculdades à atividade agrícola que aí se desenvolvia houve quem fosse procurar situação mais favorável em outras terras. Assim nasceu a colônia de Santa Maria.

As tropas legalistas obtiveram seus mantimentos e produtos fabris, da região colonial, além de inúmeros combatentes contra os separatistas. Para isso, o Estado recorreu a inúmeros mecanismos, a fim de manter os imigrantes ao lado do partido legalista. Emitiu uma "proclamação", onde assinalava ser inaceitável a participação deles junto aos farrapos, entendendo isto como uma traição. Ressaltou que a garantia do desenvolvimento da agricultura, do comércio e da indústria, o qual estava sendo ameaçado pelos "anarquistas", poderia ser assegurado caso os imigrantes aderissem à causa legalista, com o quê mostrariam, o seu agradecimento ao governo imperial que os hospedou ${ }^{60}$.

Esses dez anos de guerra foram muito representativos para a população da área colonial de São Leopoldo, pelo fato de estarem envolvidos em questões mais gerais, referentes à Província e ao Império. Com isto os colonos aperceberam-se de que eram um segmento importante dessa Província, em termos populacionais e econômicos. Prova disto foi dada pelo próprio governo provincial, que, em 27.5.1846, elevou São Leopoldo, pela Lei n O 55, à categoria de município e seu núcleo à vila. Concedeu, ainda, a naturalização, sem custas e sem maiores burocracias, assim como agradeceu, em ofício, os préstimos de Hillebrandt - diretor da Colônia (indiretamente agradecendo aos colonos) - ao governo imperial.

Os acontecimentos desse período revelaram também o quanto esses habitantes, na maioria ainda estrangeiros, desempenharam uma função decisiva aos interesses do Estado. A disputa que existiu entre farrapos e legalistas para ver quem os tinha como adeptos não era gratuita. Sabiam que o partido que conseguisse a sua adesão estava bem respaldado e poderia com isto ter a vitória assegurada.

Os colonos alemães que regressaram da Guerra Cisplatina ${ }^{61}$ ao historiar as precárias condições em que viveram nesta guerra, provocaram, no mínimo, indignação e insegurança entre os seus compatriotas. E já eram estes sentimen-

\footnotetext{
${ }^{59}$ Diz Porto que "os colonos da Povoação (...) em sua quase totalidade, estavam ao lado dos farroupilhas". (Porto, op. cit., p. 127). Porém a atuação de Hillebrandt e a repressão do governo provincial reverteram a situação.

${ }^{60}$ Conforme correspondência expedida pelos presidentes da Província a autoridades provinciais. (1822-1870) Arquivo Histórico do R.G.S., A-5-71, 8.7.1836).

${ }^{61}$ Observa-se que, apesar de tantos sacrifícios desses indivíduos, o Marquês de Barbacena, em of ício ao Presidente da Província, acusou-os de não terem prestado os serviços que deles esperava. (Citado em Porto, op, cit., p. 96).
} 
tos suficientes para que eles se vissem como "presa fácil" nas mãos desse Estado, podendo a qualquer momento serem por ele solicitados para isso ou para aquilo. Procuraram, então, se proteger dessa razoável ameaça, e uma das formas por eles encontrada foi a de "mostrar serviço", ou seja, serem eficientes naquilo para o que haviam sido indicados a realizar aqui.

Quanto à Revolução Farroupilha, diria que, de todas as repercussões desta guerra no sentido de emitir posturas e valores aos imigrantes sobre trabalho, o que mais importou foi o sentimento que aos poucos foi despertando neles de estarem na sua pátria, e não em uma terra totalmente estranha. Assim, quando tal sentimento foi oficializado pela naturalização, trabalharam tanto ou mais do que antes. Viam-se efetivamente instalados, mesmo não tendo, com isso, esquecido o tipo de Estado com que contavam.

Pelas considerações feitas nesse item, verifica-se que o Estado recorreu à legislação com muita freqüência. Daí é fácil inferir o seu significado no que diz respeito à socialização dos imigrantes alemães e descendentes relativa ao trabalho. Ela delineou e estabeleceu, inclusive, as condições que teriam para realizar a sua atividade produtiva. Disto à emissão de uma ética para o trabalho não houve uma separação. Para vencer as imposições advindas da legislação, era indispensável muito trabalho e sua realização da forma mais austera possível. É importante observar que, na maioria das vezes, as leis não passavam de letra morta. Éram promulgadas para responder um problema novo, a um interesse mais imediato, a uma dificuldade momentânea. Logo que tais situações haviam sido sanadas, as leis eram suspensas ou esquecidas.

$\mathrm{O}$ que se questionou acima não é propriamente o fato de surgirem novas leis e outras entrarem em desuso. Afinal, este é um expediente que está à disposição do Estado, a fim de garantir a sua atuação. Salienta-se a falta de perspectivas que elas evidenciam, pelo menos à médio prazo, dificultando significativamente a prosperidade do processo de colonização pela instabilidade que gerava entre os colonos e prejudicando certos objetivos e interesses de alguns setores do Estado.

Como isso repercutiu junto aos imigrantes alemães? Sem dúvida, a legislação foi um instrumento, diria até poderoso, à socialização destes indivíduos em relação ao trabalho.

Essa quantidade de leis que não foram respeitadas pelo Estado, fez com que o imigrante formasse a sua concepção de Estado, percebendo-o como caloteiro, sem palavra ("sem lei"), enganador. Captaram também a forma como ele os percebia: como inferiores em relação a outros segmentos sociais, dispensando, assim, respeito e consideração naquilo que solicitavam; caso quisessem subsistir, tinham que lutar com suas próprias forças, pois o Estado não pretendia investir mais (além da doação do lote e alguns subsídios) nesse empreendimento, esperando apenas colher dele os frutos. 
Obviamente, esse conjunto de elementos conduziu os imigrantes alemães e seus descendentes a trabalharem sempre mais. Afinal, a sua sobrevivência estava em suas mãos, com a ajuda, no máximo, dos vizinhos, os quais também enfrentavam as mesmas dificuldades.

Reivindicar os seus direitos ou expressar suas insatisfações mais do que eles o fizeram seria quase impossível. Isto considerando as condições dos imigrantes e o nível de repressão do Estado, o qual se agilizava com a maior rapidez, quando tais manifestações - as dos imigrantes - não sintonizavam com os seus interesses.

\subsection{Atividades Econômicas}

Este item objetiva, basicamente, mostrar que neste período os imigrantes socializaram-se através das próprias atividades em que participavam ${ }^{62}$. Isto porque, em função das características e condições do processo de colonização implantado na região, inexistiam órgãos ou instituições que fornecessem aos imigrantes, de maneira sistemática e regular, orientações à sua formação para o trabalho.

Visa, também, a salientar que a atividade econômica contou com projetos e expectativas, tanto da parte do Estado, quanto da dos próprios imigrantes, e que tal atividade atingiu resultados satisfatórios para ambos, mesmo tendo que conviver com circunstâncias às vezes hostis.

Tudo o que se refere a condições básicas à sobrevivência dependeu da iniciativa e do trabalho dos recém-chegados ${ }^{63}$. Afora a morosidade da administração quanto à entrega dos subsídios e dos lotes e o descontentamento $\mathrm{e}$ impasses disto decorrentes quando os imigrantes podiam neles se instalar, eles ainda levavam um bom tempo até que pudessem colher algum fruto do seu trabalho.

Mesmo que tivesse sido agricultor na Europa, frente às condições aqui existentes, precisava reaprender tudo. Nem que para isso tivesse que retroceder, empregando técnicas mais arcaicas, as usadas pelos nativos da região, até o esgotamento do solo.

Nessa etapa inicial, os imigrantes acumularam algumas experiências (tanto pelo seu trabalho quanto pelo contato com as autoridades e população

\footnotetext{
${ }^{62}$ WORSLEY, Peter. Op, cit. V. II, p. 203.

${ }^{63} \mathrm{E}$ neste sentido que se pode concordar com as inúmeras afirmações que louvam - em obras e comemorações - as realizações dos imigrantes alemães, como grandes pioneiros. Mas, desde que fossem apontados um conjunto de motivos os quais condicionaram essa atuação do imigrante nos primeiros tempos, salientando, entre eles, o papel do Estado brasileiro que interferiu, a seu modo, neste processo, devido a sua concepção de trabalho.
} 
locais), as quais, junto com o seu conhecimento trazido da Alemanha, foram de muita utilidade, pois permitiu a sua organização em outros aspectos, os quais constituíam necessidades básicas que precisavam ser satisfeitas ${ }^{64}$.

As condições de vida dos imigrantes iam melhorando com o passar do tempo, mas às custas de muito trabalho, o que envolvia todos os membros da família durante o dia inteiro. Cada familia supria tudo o que precisava, desde a alimentação e vestuário até os utensílios domésticos. Com o aumento da produção, os colonos realizavam trocas, inicialmente entre si. Em seguida, os excedentes exigiram uma comercialização. Assim surgiu a venda - a primeira loja comercial -, que se situava no núcleo da colônia e, mais tarde, noutras picadas. A venda desempenhou outras funções que não a de comprar e vender produtos até finais da década de 50 do século passado. Era

"o ponto de reunião, o abrigo das quermesses, a parada dos viajantes. Para os colonos que viviem isolados em seus lotes, foi o lugar de descanso e o elemento de coesão, o fator social por excelência" 65 .

A atividade artesanal teve também a sua importância nesses primeiros anos de instalação dos imigrantes, pois supriu as necessidades mais imediatas relativas a vestuário, calçados e outros. Auxiliou, ainda, para aumentar a receita do agricultor.

$\mathrm{E}$, mais tarde, em função da atividade pecuária ser expressiva na província, o artesanato ligado ao couro chegou a representar $48 \%$ das exportações de São Leopoldo e ocupar o primeiro lugar entre os produtos exportados por esta colônia, até 1857.

Já em 1845, a Colônia de São Leopoldo exportava outros produtos que não eram provenientes só da agricultura, como os da pecuária, da madeira $\mathrm{e}$ do couro.

É importante lembrar que tais atividades econômicas desenvolveram-se num contexto bastante atribulado, contando com inúmeros obstáculos e dificuldades. Entre eles, cita-se: a atuação inoperante da administração junto aos colonos, a legislação instável e confusa.

Se, apesar de circunstâncias adversas tal atividade prosperou, então foi porque, de um lado, os imigrantes foram pressionados pelo Estado a trabalha-

${ }^{64} \mathrm{Com}$ tantas dificuldades "depois de dois annos, às vezes até já depois de um anno, o colono produzia o necessário para a própria subsistência”. (Conforme Petry, Leopoldo. História da coloniz açāo allemã no Rio Grande do Sul, São Leopoldo, Officinas Gráphicas Rotermund \& co., 1936, p. 24).

${ }^{65}$ ROCHE, op. cit., p. 574. 
rem, à base de punição ou de prêmio e movidos por uma boa margem de insegurança. Assim, foram submetidos ao projeto de trabalho que o Estado havia a eles designado.

De outro lado, foram estimulados pelo fato de vislumbrarem condições de vida, melhores do que as que deixaram na Alemanha. O fato de se tornarem proprietários ${ }^{66}$ aqui, foi decisivo neste sentido. Assegurou o ânimo à luta, mesmo que, às vezes, temessem não resistir aos obstáculos ${ }^{67}$. Mas, não lhes restava outra coisa: ou venciam no Brasil, ou aqui morriam, pois voltar à terra natal era inviável, até mesmo juridicamente falando. Isto porque era uma das condições impostas pelos Estados Alemães a de abdicar da sua nacionalidade, caso emigrasse.

Sendo assim, jogaram todas as suas forças e energias para não sucumbirem, isto é, para não cair por terra o seu projeto de vida, que só podia ser garantido com muito trabalho.

Porém, essa necessidade de sobrevivência num meio asfixiante e o desejo de melhorar sua posição social precária, só podiam orientá-los para preocupações, essencialmente utilitárias. Com isso, sem dúvida, outros setores da vida foram colocados em segundo plano. E, quando foi retomada a imigração, os que aqui chegavam, espantaram-se com esses habitantes, denominando-os de "bárbaros", ignorantes, materialistas e com costumes degenerados ${ }^{68}$.

Em outras palavras, os imigrantes que chegavam após 1845, defrontaram-se com aquilo que o trabalho - luta árdua pela sobrevivência - tinha feito com essas pessoas, deixando-as rudes, grosseiras, avarentas. Ou seja, alienaram-se pelo trabalho. Tudo o que as rodeava, se não estivesse ligado, diretamente, às condições básicas à garantia de suas vidas, passava por desconhecido ou até inexistente.

Foi dessa forma que o contexto lhes permitiu empreender o trabalho: como um agir que se movia na esfera da necessidade a fim de assegurarem a sua existência. Porém, esses colonos transformaram a região de São Leopoldo, que antes era uma mata fechada, e nela, com seu trabalho, inscreveram significados. Tais aspectos não se deram separadamente. Constituem-se num único processo. Mas, enquanto eles não se conscientizavam disso, o trabalho opunha-se à liberdade.

Pelas considerações aqui expostas, pode-se inferir também que, nesse

${ }^{\circ 6}$ PELlandA, Ernesto. A coloniação Germânica do Rio Grande do Sul, 1824 a 1924. POrto Alegre, Editora Globo, R.S., 1925, p. 93.

${ }^{67} \mathrm{Em}$ vários momentos, relata um imigrante: (...) "nossos corações se enchiam de pesar e o desânimo ameaçava apossar-se de nós, quando víamos as dificuldades que a cada passo encontrávamos. Porém, era forçoso hutar e lu tamos'. Citado em Petry, op. cit., p. 48.

${ }^{68}$ Mais detalhes encontra-se na obra de Roche, op. cit., p. 651-52. 
primeiro período, o trabalho alienou os imigrantes alemães, mas isto não significa dizer que viveram, ininterruptamente, num vale de lágrimas. Tiveram suas recompensas, das quais, inclusive, lisonjeavam-se ${ }^{69}$. Até os menos aquinhoados com a sorte conseguiram, de certa forma, o que almejavam ao virem para cá - tornarem-se proprietários. No ponto de vista de Dacanal, o fato dos imigrantes terem recebido um lote, deve ser visto como privilégio em relação aos marginais do sistema pré-existente (ín dios, caboclos e negros). Tal privilégio é fundamental, já que permite - como permitiu ao imigrante alemão - a sobrevivência biológica, pois fornece as condições mínimas de alimentação ${ }^{\text {D }}$.

\subsection{Atividades Educacionais, Religiosas, Culturais e Recreativas}

Neste item salientam-se os mecanismos ou instrumentos que os imigrantes dispunham para sua socialização quanto ao trabalho. Evidentemente, isto não ocorreu dissociado daqueles emitidos pelas características das bases estruturais da sociedade da época.

Sendo a família uma forma de organização já constituída na Alemanha, e por isto já conhecida dos imigrantes quando aqui chegaram, ela assumiu um papel fundamental na vida dessas pessoas, frente a tantas dificuldades a que estiveram expostos nos primeiros tempos, inclusive a ponto de constituir o centro de gravitação de todas as outras atividades por eles desenvolvidas, desde o provimento das necessidades básicas à subsistência, até a organização das atividades culturais e recreativas.

Sendo a maioria dos imigrantes parentes entre si, os laços e unidade familiares ficaram muito fortalecidos, dando à família um papel preponderante e decisivo em todas as questões da vida da colônia.

O nível de parentesco era tão elevado ${ }^{71}$, que permite afirmar ser a socialização quanto ao trabalho realizada, efetivamente, pelas experiências e vivências culturais dos próprios imigrantes alemães e pelo Estado, através de seus funcionários e legislação. Outros segmentos da sociedade brasileira e gaúcha pouco interferiram nesse processo no período em estudo.

É importante ressaltar que, mesmo o homem assumindo a posição central na família, a mulher era sempre consultada quando era necessário tomar certas decisões relativas ao núcleo familiar. In discutivelmente, a sua condição,

\footnotetext{
${ }^{69}$ Há depoimentos registrados na obra de Roche, op. cit., p. 280 e 580.

${ }^{70}$ Conforme Dacanal, José H. A imigração e a história do Rio Grande do Sul. In. Dacanal, José H. \& Gonzaga, Sergius, org. R.S. : imigraçāo \& colonização, Porto Alegre, Mercado Aberto, 1980, p. 274-277.

${ }^{71}$ Até o final do Séc. XIX, verificou-se a existência de um percentual elevado de endogamia.
} 
por gozar de alguns direitos, era bastante superior à da mulher gaúcha na época.

A familia constituía-se, em todos os momentos, num centro de trabatho. Assim, o descendente do imigrante alemão, desde muito pequeno, sempre viu todos os familiares envolvidos no trabalho ${ }^{72}$ desde os seus irmãos ou irmãs mais velhos até os seus avós. Então, a partir do que observava, ficou sempre muito claro para ele que o normal, o saudável, o certo era trabalhar no decorrer de toda vida e desde muito cedo.

Os costumes e valores foram muito rigorosos durante o Séc. XIX e, e em especial, nas primeiras cinco décadas da colonização. E, neste sentido, a família contribuiu decisivamente, até porque um dos valores mais arraigados entre eles era a noção de famulia. Sendo assim, foi se passando de pai para filhos - durante algumas gerações - valores como: coragem, presteza, espírito de economia, os quais relacionavam-se diretamente com trabalho, no tocante ao aspecto ético ${ }^{73}$.

Depois que o grupo familiar já tinha conseguido suprir as necessidades básicas à sua sobrevivência - às custas de muito trabalho -, pôde então dedicar algum tempo à criação de certas condições indispensáveis à sua vida em comunidade, inclusive por se constituírem em garantias à continuidade do trabalho produtivo. Uma das primeiras iniciativas referiu-se ao provimento de "aulas" aos seus filhos.

Não que isto estivesse assegurado a eles na Alemanha, pois viviam em precárias condições também quanto ao aspecto educacional, pois entre os que chegaram aqui nos primeiros tempos, alguns eram analfabetos.

Inicialmente, o ensino para crianças realizou-se em casas particulares, por algum membro mais letrado da comunidade ou, na falta deste, por uma pessoa idosa que não pudesse mais prestar os seus serviços na lavoura ${ }^{74}$.

Mais tarde é que surgiu a figura do professor, o qual estava submetido aos interesses da comunidade, desprovido de qualquer autonomia, já que era por ela contratado. A administração pública manteve-se, em geral, insensível aos pedidos dos colonos para o suprimento de escolas e professores.

${ }^{72} \mathrm{Diz}$ Roche que somente no 2 ? período, (...) "quando a familia atinge uma relativa abastança, exige-se menos trabalho das crianças salvo durante as férias". (...) "Também a avó, que fica ern casa cuida da cozinha, enquanto o avô se ocupa de pequenos trabalhos de jardinagem, de vedação, de conservação das construções"... (Citado em Roche, op. cit., p. 559).

${ }^{73}$ ROCHE, op. cit., p. 639.

${ }^{74}$ SCHUTZ, Liane Maria Martins. Imigração alemã: processos, costumes e influências. In: Anais do 1 ? Simpósio de História da imigração \& colonização alemã no R.S. São Leopoldo, Gráfica Rotermund S.A., 1974, p. 292. 
Enfatiza-se que foram duas as escolas oficiais até 1846 e, portanto, ineficientes como veículos das características das bases estruturais da sociedade brasileira, eficientes porém do ponto de vista do projeto de trabalho dos imigrantes. Isto porque não alteraram, mas apenas reforçaram as normas e os valores dominantes na vida da Colônia de São Leopoldo.

Outro aspecto de muita importância a todos os imigrantes, independentes da seita que cultuassem, foi o papel da religião. $O$ isolamento em que se encontravam, a coesão familiar e o controle da comunidade fizeram com que aumentasse o sentimento de religiosidade entre os imigrantes ${ }^{75}$.

Outras atividades de caráter mais recreativo, como a banda, o "Kerb", o canto coral, os quais se constituíram também em atividades, parcialmente culturais, nesse primeiro período não tiveram também uma maior organização: realizavam-se de forma assistemática e informal, geralmente nas casas dos próprios imigrantes. Serviram porém, para elevar o nível de solidariedade entre os habitantes ${ }^{76}$.

Essa solidariedade transparecia, também nos momentos de festas e comemorações e não apenas quando tinham que manifestar os seus protestos frente às atitudes do governo, frente à colonização ou ainda, quando tinham que se organizar em associações ou comissões, para sanarem suas dificuldades.

Um dos locais de encontros e festejos, quando o trabalho agrícola começou a gerar alguns excedentes, foi a venda. Aí bebiam em comemoração às boas colheitas, jogavam bolão nos domingos e feriados e realizavam o famoso "Kerb" 77, depois de assistir ao culto. Passavam três dias inteiros, em efusiva confraternização, fazendo as refeições em familia, divertindo-se nas quermesses e participando dos bailes, ao som de músicas alemãs.

Certamente essa foi a forma encontrada pelos colonos - que lutavam de sol a sol - para angariarem forças para continuar a luta pela sobrevivência, que ainda não estava de todo assegurada ${ }^{78}$. Constituía-se num brinde a eles mesmos, pelo que estavam enfrentando e conquistando.

\footnotetext{
${ }^{75}$ ROCHE, op. cit., p. 671.

${ }^{76}$ Esta solidariedade surgiu como um mecanismo, como uma garantia à sobrevivência dos imigrantes. Assim, para resolver qualquer problema que existia na área colonial, reuniamse, formavam associações (religiosas, educacionais), elegiam comissões, as quais se encarregavam das decisões, sobre construção de igrejas, escolas, pontes, limpeza dos cemitérios... Tudo isso envolvia muitas discussões e debates, até chegarem a um consenso. (Conforme Amado, op. cit., p. 43 a 48).
}

${ }^{77} \mathrm{O}$ Kerb de Dois Irmãos é o mais antigo do Estado. Era conhecido como "Michelskerb", festejado no dia de São Miguel a 29 de setembro, desde o ano de 1829. Há mais detalhes sobre Kerb na obra de Carlos de Souza Moraes. $O$ colono alemäo - uma expe. riência vitoriosa a partir de São Leopoldo. Porto Alegre, EST. 1981, p. 125 a 138.

${ }^{78}$ Esta é a opinião, também de Moraes, op. cit., p. 139. 
O canto foi muito cultivado entre os imigrantes alemães, era uma das coisas que muito apreciavam. Cantavam para se divertir, para matar as saudades da Alemanha, para se comunicar... E assim, foram estabelecendo ligações entre as duas pátrias e solidificando as suas relações com a mais recente ${ }^{79}$.

Sem dúvida, esse conjunto de atividades desempenhou um papel muito importante na adaptação dessas pessoas à nova pátria. Por meio delas, sentiam-se identificados, facilitando a união entre eles em outros aspectos da vida que não fosse apenas o da luta, do trabalho diário e do sofrimento. Assim, tais atividades funcionaram como uma fonte vitalizadora para o imigrante continuar o seu empreendimento.

Pelo que foi exposto até aqui, fica evidente que a Colônia de São Leopoldo funcionava como uma grande família, sendo muito forte o papel da comunidade em relação a outros fatores da vida da Colônia, como o sistema educacional e religioso, os quais se constituíram em fontes de explicação do mundo, sendo assim muito importantes para a formação e evolução da Colônia.

\section{Conclusão}

$\widehat{E}$ indiscutível que os imigrantes alemães ficaram caracterizados como alguém que se dedicava intensamente ao trabalho. Porém, alguns estudos, ao relacionarem este fato com o abandono do colono alemão pelo Estado Brasileiro, propõem uma visão apologética do trabalho desenvolvido por estes indivíduos, pouco auxiliando à compreensão do fenômeno.

Por isso, é importante que não se omita o fato de que os imigrantes alemães contaram com certas circunstâncias que definiram a sua atuação no mundo do trabalho e da produção, desde os motivos que os conduziram à emigração até as suas expectativas e as do Estado brasileiro, em relação a tal empreendimento.

Em vista das considerações expostas até aqui, conclui-se que os colonos alemães não foram abandonados pelo Estado brasileiro e que este não agiu como um vilão com os imigrantes, nem nesse período em estudo e muito menos nos seguintes. Até porque os imigrantes, em relação aos segmentos marginais do sistema pré-existente, podem ser vistos como privilegiados pelo Estado brasileiro, já que obtiveram uma propriedade que lhes garantiu a subsistência. $\mathrm{Ou}$ seja, concretizaram o seu projeto de vida, que foi o de correr riscos com a

\footnotetext{
${ }^{79}$ F oi publicado um livro que trata, basicamente, do significado e do papel da canção para o imigrante alemão. A obra é de FLORES, Hilda A. H. Cançâo dos Imigrantes. Porto Alegre, EST, Univ. de Caxias do Sul, 1983.
} 
emigração em troca de um quinhão de terra para se instalarem.

O Estado brasileiro precisava, nem que fosse à força, que o seu projeto também desse certo. Por isto exerceu uma postura de controlador, fiscalizador e explorador junto aos imigrantes alemães, mas não teve uma postura de abandono. E, considerando a formação social brasileira na época, reforça-se o fato de que o que houve, efetivamente, foi exploração e não abandono dos imigrantes alemães por parte do Estado. Não há nada de extraordinário nessa colocação, já que as características da estrutura social em que o processo de colonização estava inserido sustentava-se em bases capitalistas, as quais já permeavam a sociedade brasileira. E sabe-se que a essência desse modo de produção é a exploração nas relações sociais de produção.

A afirmação de que o Estado abandonou os imigrantes alemães ao seu destino, a partir do tipo de atuação que ele teve junto à área colonial alemã, pode estar omitindo a concepção deste Estado, nesse momento, relativa ao trabalho, a qual apresentava uma correlação direta com trabalho manual e todas as implicações que disto decorria.

Enfim, a atuação do Estado brasileiro e a de outros segmentos da sociedade da época estavam vinculadas a algumas razões, e, entre elas, indiscutivelmente, a sua concepção sobre trabalho, oriunda da constituição da sociedade naquele momento.

Conclui-se, assim, que neste primeiro período da colonização alemã no Rio Grande do Sul, a socialização do imigrante alemão e de seus descendentes, no tocante ao trabalho, processou-se tanto pelas características das bases estruturais da formação social brasileira - via Estado - quanto pelas experiências e vivências dos próprios imigrantes alemães, tanto as que já faziam parte da sua história quando aqui chegaram, como também aquelas obtidas na nova terra, as quais foram influenciadas pelas características das bases estruturais da formação social do Brasil na época.

Ao finalizar, destaca-se que tais conclusões não abrangem a complexidade do fenômeno como um todo e que muitos aspectos ainda carecem de maior aprofundamento. Isto especialmente quanto a outras dimensões referentes ao período e tema aqui considerados, as quais poderiam ampliar e enriquecer este estudo.

*Pontifícia Universidade Católica do Rio Grande do Sul Departamento de Ciências Sociais

90610 - Porto A legre 